\title{
Gender Difference in Formative Assessment Knowledge of Senior High School Teachers in the Upper West Region of Ghana.
}

\author{
Daniel Asamoah* $^{*}$ Sauri Songnalle Benjamin Sundeme Charles Derkye \\ Department of Education and Psychology, University of Cape Coast, Ghana
}

\begin{abstract}
The study sought to investigate gender difference in formative assessment knowledge of Senior High School teachers in the Upper West Region of Ghana. The descriptive survey design was used in the study. Simple random sampling was used to select a sample of 295 senior high school teachers from a population of 1139 teachers. A self-developed questionnaire was used to collect data for the study and the gathered data was analysed using independent $t$-test. The findings of the study revealed a significant difference in the formative assessment knowledge of male and female senior high school teachers and that male senior high school teachers do better in their formative assessment knowledge than their female counterparts. Recommendations were made based on the organisation of seminars and workshops by educational stakeholders to enhance the formative assessment knowledge of senior high school teachers and especially female teachers.
\end{abstract}

Keywords: Formative assessment knowledge, Senior high school teachers, Gender

DOI: $10.7176 / \mathrm{JEP} / 10-6-08$

\section{Introduction}

All over the world, there has been numerous criticisms regarding the practice of summative assessment with respect to the fact that, its practice bestows a harmful effect on students' learning (Kapambwe, 2010). In line with this, educators from various contexts are beginning to pay a particular attention to formative assessment because, it serves as a reliable instructional tool for raising students' achievement (Wei, 2010). Formative assessment and the procedures that are associated with it are now strongly advocated for use in educational interventions such as classroom instructional practices and teacher professional development (Wei, 2010). The goal is to address the gap between students' current performance and the expected performance in order to achieve accountability standards (Kingston \& Nash, 2011; McMillan, Venable, \& Varier, 2013). As indicated by Clarke (2012), assessing students' learning outcomes should no longer be based on the end results but should seek to monitor the growth of students' learning. Formative assessment encourages lifelong learning among students and as a result, it should be integrated with instruction to help in developing students' learning and not just be seen a measurement oriented activity (Careless, 2008). It therefore follows that in order to achieve an effective instruction, assessors must assess their students during the instruction in order to gain information about students' progress and understanding. This is quintessential because when it is done, instruction can be adapted accordingly.

With reference to the current trends in assessment, the 2007 Education Reform in Ghana strongly recommended a reduction in the traditional paper, and pencil test and examination-oriented education, and focus on education that promotes critical and problem solving skills, which can be attained meaningfully through the practice of formative assessment (Oduro, 2015). For this to be feasible, various assessment technique such as portfolios, observations and projects among others were recommended by the Curriculum Research Development Division to assess students' learning outcomes. Although these reforms are laudable, there are concerns on how they can be implemented to meaningfully actualise the assessment practices in the Ghanaian schools (Akyeampong, Djangmah, Oduro, \& Seidu, 2007).

In view of the role that formative assessment plays in the instructional environment, there is therefore the need to investigate how well teachers are knowledgeable in formative assessment in order to improve teaching and learning. This is important because, assessors which include teachers use assessment techniques for the purposes of assigning grades (Alkharusi, Aldhafri, Alnabhani \& Alkalbani, 2014). In the case of Ghana, AmuaSekyi (2016) revealed that most Ghanaian teachers see feedback on formative assessment as a difficult role and therefore use grades to assess students' work. This therefore allows for comparison between students rather than improving the entire instructional experience thereby placing priority on summative assessment to the neglect of formative assessment.

Teachers with varying characteristics such as level of assessment knowledge have different explanations for their varying assessment practices (Koloi-Keaikitse, 2012). It is in this respect that Alkharusi, et al. (2012), in a study on educational assessment attitudes, competence, knowledge, and practices of 165 teachers in the Sultanate of Oman revealed that teachers' assessment knowledge, among other variables do influence teachers' formative assessment practices. In other jurisdictions, educators have recognized that teachers' assessment knowledge influence their formative assessment practices. For example, Stiggins (as cited in Mohamed, et al., 2016) contended that strong knowledge in educational assessment is a basic requirement for effective formative 
assessment practices in the classroom. A careful analysis of literature clearly suggest that a teacher's formative assessment knowledge has an influence on his/her formative assessment practice in the classroom (KoloiKeaikitse, 2012; Alkharusi, et al., 2012). It can therefore be concluded that what teachers know about assessment is a significant factor that influences their assessment practices and what they do with the data they collect from students' assessment. This means further that teachers who are knowledgeable about classroom assessments are more likely to practice formative assessments effectively because they are more likely to integrate assessment data into their instruction in order to improve teaching.

Empirical studies both locally and internationally suggest that teachers' knowledge of formative assessment affects their practice of assessment. For instance, from a sample of 543 teachers in the Edo State, Alufohai and Akinlosotu (2016) in their study revealed that majority of the teachers in secondary schools in Esan Central Senatorial District of Edo State did not have adequate knowledge in continuous assessment and that male teacher have a relatively high knowledge than their female counterparts. In addition, Alkharusi et al. (2012) from a sample of 156 Muscat in-service teachers in the Sultanate of Oman revealed that teachers demonstrated low level of knowledge in educational assessment. In Asia, Quyen and Khairani (2017) revealed that teachers lacked knowledge in the practice of formative assessment in Asian classrooms and that hindered their practice of formative assessment. It was noted that teachers did not understand the concept of formative assessment or how to implement it in their classrooms, however, male teachers tend to exhibit formative assessment knowledge than females Quyen \& Khairani, 2017). In Ghana, Awoniyi (2016) concluded form a sample of 110 teachers in Cape Coast that teachers did not understand School-Based Assessment guidelines as part of formative assessment which means these teachers are not abreast with new trends and development relating to assessment practices. In addition, a study by Kankam, Bordoh, Eshun, Bassaw and Korang (2014) from a sample of twenty social studies teachers revealed that teachers lacked knowledge in formative assessment practices.

Although empirical studies have suggested that teachers have low knowledge in the practice of formative assessment, none the studies conducted locally and internationally focused on finding out if gender differences exist in teachers' formative assessment knowledge which influence their practices of formative assessment. The studies form Ghana on formative assessment as indicated above focused on teachers' knowledge in formative assessment but they failed to assess how senior high school teachers differ in their formative assessment knowledge with respect to gender. As a result and with reference to the Upper West Region, there is no readily available information on how male and female Senior High School teachers differ in their formative assessment knowledge. Looking at the lacuna that has been created in literature, and with reference to the fact that the Upper West Region has numerous professional and non-professional senior high school teachers, there is the need to investigate if gender difference exists in senior high school teachers' formative assessment knowledge. The study sought to find out the gender differences in the formative assessment knowledge of senior high school teachers in the Upper West Region of Ghana.

\section{Hypothesis}

$\mathrm{H}_{0}$ : There is no statistically significant difference in male and female Senior High School teachers' formative assessment knowledge in the Upper West Region of Ghana.

$\mathrm{H}_{1}$ : There is a statistically significant difference in male and female Senior High School teachers' formative assessment knowledge in the Upper West Region of Ghana.

\section{Methodology}

The study used the descriptive survey design. The study area was the Upper West Region which is one of the ten regions of Ghana. The population was made up of 1139 senior high school teachers from 35 senior high schools in the region. Through simple random sampling procedures, 285 senior high school teachers were selected form the population. The 285 respondents were selected based on a recommendation by Krejcie and Morgan's (1970) table of sample size determination that indicates that the appropriate sample size for a population of 1139 is 285 . A survey questionnaire on formative assessment knowledge was used to collect data for the study. The questionnaire contained seventeen items which were measured on a four-point Likert scale namely $1=$ Strongly Disagree, 2 = Disagree, $3=$ Agree and 4=Strongly Agree with 1 indicating the least agreement with the statements and 4 indicating the highest agreement to the statements. To improve on the validity and reliability of the instrument, it was given to experts in the field of measurement and evaluation in order to judge each item in the context of clarity, generality and ambiguity. In addition, a pilot test was conducted using 50 senior high school teachers in the Central Region of Ghana. After the pilot testing, Cronbach's Alpha was used to judge the reliability of the items on the instrument and the reliability coefficient stood at .70 which according to Pallant (2010) is good for a better generalization. Before the field work, permissions were sought from the authorities of the sampled schools for the data collection exercise. On the field, the administration of the instruments was done in one month and the researchers with four trained field assistants, administered the instruments to the respondents. Respondents were assured of the necessary ethical issues such as confidentiality, anonymity and 
right of participation. At end of the data collection, all the 285 questionnaires were completed and collected. Teachers' formative assessment knowledge was obtained by scoring the seventeen items in line with their measurements and the scores ranged from 17 to 68 . For each of the items, a correct formative assessment knowledge item had a highest score of 4 when a respondent ticks under 4 and a lower score of 1 when a respondent ticks under 1 . The data was coded into SPPS for cleaning, and checking of errors and missing values. The statistical tools that was used to analyse the data was independent t-test.

\section{Results and Discussion}

Before the conduct of the analysis, assumptions that underlie the conduct of independent t-test were fulfilled. Prominent among these assumption were normality and homogeneity of variance. Specifically, the normality assumption was checked. It was revealed that gender was normality distributed on formative assessment knowledge scores $(\mathrm{p}=.56$ and .67 for males and females respectively, which were all greater than .05). Furthermore, the homogeneity of variance assumption was also checked and it was revealed that variances were assumed to be equal $(\mathrm{p}=.521>.05)$. The summary of the result after the analysis using the independent $\mathrm{t}$-test is presented in Table 1.

Table 1: Independent t-test on SHS teachers' formative assessment knowledge

\begin{tabular}{|c|c|c|c|c|c|c|c|}
\hline $\begin{array}{c}\text { Levene's Test } \\
\text { for Equality } \\
\text { of Variances } \\
\end{array}$ & \multicolumn{7}{|c|}{ t-test for Equality of Means } \\
\hline \multirow[t]{2}{*}{$\mathrm{F}$} & \multirow[t]{2}{*}{$\mathrm{T}$} & \multirow[t]{2}{*}{ Df } & \multirow[t]{2}{*}{$\begin{array}{l}\text { Sig. (2- } \\
\text { tailed) }\end{array}$} & \multirow[t]{2}{*}{$\begin{array}{c}\text { Mean } \\
\text { Difference }\end{array}$} & \multirow[t]{2}{*}{$\begin{array}{l}\text { Std. Error } \\
\text { Difference }\end{array}$} & \multicolumn{2}{|c|}{$\begin{array}{l}95 \% \text { Confidence } \\
\text { Interval of the } \\
\text { Difference }\end{array}$} \\
\hline & & & & & & Lower & Upper \\
\hline .521 & 2.248 & 293 & .025 & 1.652 & .735 & .206 & 3.097 \\
\hline & 2.207 & 218.37 & .028 & 1.652 & .749 & .176 & 3.127 \\
\hline
\end{tabular}

assumed

Source: Field survey (2018)

It is evident from Table 1 that the test is significant, and that the null hypothesis $\left(\mathrm{H}_{0}\right)$ is rejected. This is because considering $\underline{\mathrm{t}}(293)=2.248, \underline{\mathrm{p}}=.025<.05$ under equal variance assumed, it is evident that a significant difference exists in the means of the male and female teachers with respect to their knowledge on formative assessment. The difference between male and female SHS teachers in their knowledge of formative assessment is showed in the descriptive statistics which is presented in Table 2.

Table 2: Descriptive statistics showing a difference in the means of male and female teachers with respect to their formative assessment knowledge

\begin{tabular}{llllll}
\hline & Gender & $\mathrm{N}$ & Mean & Std. Deviation & Std. Error Mean \\
\hline \multirow{2}{*}{ Knowledge } & Male & 184 & 41.23 & 5.933 & .437 \\
& Female & 111 & 39.58 & 6.400 & .607 \\
\hline
\end{tabular}

Source: Field survey (2018)

From the descriptive statistics that is shown in Table 2, it is clear that with respect to the formative assessment knowledge of the teachers that were sampled, male teachers had the highest mean of 41.23 with a standard deviation of 5.933 whereas female teachers had a mean of 39.58 with a standard deviation of 6.400. The mean difference is 1.65 and this explains that male teachers have more knowledge than their female counterparts when it comes to formative assessment. For the hypothesis that was set for the study, the finding of the study revealed a significant difference between male and female senior high school teachers and that male teachers do better in their formative assessment knowledge than their female counterparts. According to Alufohai and Akinlosotu (2016) who found in their study that teachers in secondary schools do not have adequate knowledge in formative assessment, it was revealed further that male teachers have a relatively high knowledge than their female counterparts. The positions of Alufohai and Akinlosotu (2016) have been justified regarding the respondents who were surveyed. The result might be as a result of the ability of male teachers to be explorative and more enthusiastic to find out more on formative assessment knowledge (Alufohai \& Akinlosotu, 2016). The finding of the study further confirms the positions of Quyen and Khairani (2017) who in their study revealed that although teachers lacked knowledge in the practice of formative assessment in Asian classrooms, male teachers tend to exhibit formative assessment knowledge than females. It can be observed that the finding of the study is consistent with literature on formative assessment knowledge. A notable explanation to the finding according to Alkharusi et al. (2012) might be that male teachers might have explored more on formative assessment and its 
practices as compared to female teachers. The exploration might have given them the insight and the confidence which make male teachers exhibit more knowledge in formative assessment than their female counterpart.

\section{Conclusions and Recommendations}

It is evident form the finding of the study that male senior high school teachers have more knowledge in formative assessment knowledge than their female counterparts. This suggests that male teachers are more likely to explore more on their formative assessment knowledge, use varied assessment methods and are confident in their practice of formative assessment than their female counterparts. This might have happened in the case of the respondents that were surveyed. It can be concluded further that male senior high school teachers in the Upper West Region have more knowledge on formative assessment than female senior high school teachers. It should be pointed out that the finding from this study is quintessential to educational stakeholders. With reference to the finding, it is recommended that female teachers should be encouraged by stakeholders in education such as governments, Ghana Education Service, parents and the Ministry of Education to learn and practice new trends of formative assessment. This will expose them to the current ideas and conceptions of formative assessment. In addition, the study recommends the need to organise seminars and workshops by the Ghana Education Service and heads of schools, among others, on the current trends on formative assessment to senior high school teachers. When seminars and workshops are organised and facilitated by assessment experts, they will enhance the knowledge of senior high school teachers in formative assessment.

\section{References}

Akyeampong, A. K., Djangmah, J., Oduro, A. \& Seidu, A. (2007). Access to basic education in Ghana: The evidence and the issues. Sussex: University of Sussex, UK.

Alkharusi, H., Aldhafri, S., Alnabhani, H., \& Alkalbani, M. (2012). Educational assessment attitudes, competence, know3ledge, and practices: An exploratory study of Muscat teachers in the Sultanate of Oman. Journal of Education and Learning, 1(2), 217- 232.

Allen, M. J., \& Yen, W. M. (2002). Introduction to measurement theory. Waveland: Waveland Press Inc.

Alufohai, P. J., \& Akinlosotu, T. N. (2016). Knowledge and attitude of secondary school teachers towards continuous assessment practices in Esan Central Senatorial District of Edo State. Journal of Education and Practice, 7(10), 71-79.

Amua-Sekyi, T. E. (2016). Assessment, student learning and classroom practice: A review. Journal of Education and Practice, 7(21), 1- 6.

Awoniyi, F. C. (2016). The understanding of senior high school mathematics of teachers of school-based assessment and its challenges in the Cape Coast Metropolis. European Centre for Research Training and Development, 4(10), 22-38.

Baird, J. A. (2011). Does the learning happen inside the black box? Assessment in Education, Principles, Policy and Practice, 18, 343-345.

Careless, D. (2008). Learning oriented assessment: Principles, practices, and a project. Victoria: University of Wellington.

Clark, I. (2015). Formative assessment: Translating high-level curriculum principles into classroom practice. Curriculum Journal, 26(1), 91-114.

Clarke, M. (2012). What matters most for student assessment systems: A framework paper. Washington, D.C: The International Bank for Reconstruction and Development, World Bank.

Greenstein, L. (2010). What teachers really need to know about formative assessment. New Jersey: ASCD.

Kankam, B., Bordoh, A., Eshun, I., Bassaw, K. T., \& Korang, Y. F. (2014). An investigation into authentic assessment practices of social studies teachers in the senior high schools in Ghana. American Journal of Social Sciences, 2(6), 166-172.

Kapambwe, W. M. (2010). The implementation of school based continuous assessment in Zambia. Educational Research and Reviews, 5(3), 99-107.

Kingston, N., \& Nash, B. (2011). Formative assessment: A meta-analysis and a call for research. Educational Measurement: Issues and Practice 30 (4): 28-37.

Koloi-Keaikitse, S. (2012). Classroom assessment practices: a survey of botswana primary and secondary school teachers. Published masters' thesis, Universsity of Botswana, Botswana.

Krejce, R. V., \& Morgan, D. W. (1970). Determining Sample Size for Research Activities. Education and Psychological Measurement, 30, 607-610.

McMillan, J. H., Venable, J. C., \& Varier, D. (2013). Studies of the effect of formative assessment on student achievement: So much more is needed. Practical Assessment, Research \& Evaluation, 18(2), 81-89.

Mohamed, S., Kamis, A., \& Ali, N. (2016). Gauging the assessment literacy of Malaysia's home economics teachers: An empirical study. Malaysian Journal of Society and Space, 12(3), 130 - 138.

Oduro, O. E. (2015). Assessment in mathematics classrooms in Ghana: A study of teachers' practices. A 
doctoral thesis submitted to the University of Sussex, United Kingdom.

Pallant, J. (2010). SPSS survival manual (4 ${ }^{\text {th }}$ ed.). New York: McGraw Hill.

Popham, W. J. (2007). The lowdown on learning progressions. Educational Leadership, 64(7), 83-84.

Quyen, D. T. N., \& Khairani, Z. M. (2017). Reviewing the challenges of implementing formative assessment in Asia: The need for a professional development program. Journal of Social Science Studies, 4(1), 160-177.

Stiggins, R. (2009). Assessment for learning in upper elementary grades. Phi Delta Kappan, 90, 419-421.

Wei, L. (2010). Formative Assessment: Opportunities and challenges. Journal of Language Teaching and Research, 1(6), 838-841. 